\title{
Designing and modeling innovation across scales for urban water systems
}

\author{
M. Santelmann ${ }^{1}$ (D) $\cdot$ D. Hulse ${ }^{2} \cdot$ M. Wright ${ }^{3} \cdot$ C. Enright ${ }^{4} \cdot$ A. Branscomb ${ }^{4} \cdot$ M. Tchintcharauli-Harrison ${ }^{1} \cdot$ J. Bolson $^{5}$
}

Published online: 16 July 2019

(C) The Author(s) 2019

\begin{abstract}
Effective, sustainable management of urban water systems, including drinking water, stormwater, wastewater, and natural water systems, is critical to the health and well-being of people in urban areas and the ecosystems that encompass them. The demands of human population growth, aging infrastructure, and changing climate will increase pressure on these systems and require future innovations in water management. Planning for urban water systems will increasingly require collaborations between water professionals and researchers to imagine, design and model the response of novel urban water systems to future conditions. We highlight benefits and challenges of transdisciplinary projects for integrated urban water management; organized broadly into: (1) engagement of water managers and planners; (2) transdisciplinary design of innovative systems, and once designed; (3) modeling and evaluation of urban water system response to various innovations. We describe the development of a multi-scale approach to design and evaluation of innovative urban water systems, and illustrate its application using examples from the Willamette River Basin and Portland, Oregon. The scenario-based approach described here offers several key contributions to the design and modeling of innovation. First, this process provides the opportunity to convene professionals and researchers, who do not typically collaborate, as participants in a collaborative process. Second, it engages participants in thinking together across land and water management sectors to develop plausible futures at multiple spatial extents and multidecadal time horizons. Third, it helps to identify critical gaps in extant water modeling capabilities, and thus helps define the near-term research agenda for modelers.
\end{abstract}

Keywords Multi-scale modeling $\cdot$ Alternative future scenarios $\cdot$ Transdisciplinary

\section{Introduction}

"Harvesting experience (i.e., systematically and rigorously validating and documenting examples of success in Sustainable Urban Water Management) is needed to build

M. Santelmann

Mary.Santelmann@oregonstate.edu

D. Hulse

dhulse@ufl.edu

M. Wright

Maria.Wright@oregonstate.edu

C. Enright

cenright@uoregon.edu

A. Branscomb

allanb@uoregon.edu

M. Tchintcharauli-Harrison

harrimic@oregonstate.edu a robust evidence base for the implementation of "what has already worked" in new locations so that resources can be directed toward appropriate adaptation to local contexts rather than wholesale reinvention."

J. Hering and K. Vairavamoorthy (2018)

J. Bolson

jbolson@fiu.edu

1 College of Earth, Ocean, and Atmospheric Sciences, Oregon State University, 104 CEOAS Administration Building, Corvallis, OR 97331, USA

2 Florida Institute for Built Environment Resilience, University of Florida, Gainesville, FL 32601, USA

3 Institute for Water and Watersheds, Oregon State University, 234 Strand Hall, Corvallis, OR 97331, USA

4 Institute for a Sustainable Environment, 5249 University of Oregon, Eugene, OR 97403-5249, USA

5 Department of Earth and Environment, Florida International University, Miami, FL 33199, USA 
Sustainable management of urban water supply, stormwater, and wastewater, is critical to the health and well-being of people in urban areas, and to ecosystems affected by urban land and water use. The demands of population growth, aging infrastructure and changing climate will increase pressure on all of these systems in the future. Here, we describe an approach that builds on the concept of the city blueprint (a framework to assess urban water sustainability of cities globally) to identify vulnerabilities in the urban water system at the spatial extent of entire cities, and then uses multi-scale design and evaluation of alternative future scenarios to explore and inform decision makers of the potential outcomes of different options. Our approach uses basin-scale modeling to characterize the regional context for the scenarios. Finer-scale modeling and evaluation of the scenarios at the spatial extent of watersheds and urbanizing neighborhoods is used to evaluate options and provide information to managers at scales relevant to their decision-making needs.

While urban areas occupy only about $3 \%$ of the world's land surface (Liu et al. 2014), they have a disproportionate impact on the hydrologic regimes of associated river systems and their water quality. The proportion of the world's population living in cities is expected to reach $66 \%$ by 2050 . More than $70 \%$ of global greenhouse gas emissions are contributed by energy use in urban areas, and just 50 of the world's largest cities draw their water supply from watersheds covering $41 \%$ of the world's land surface (NSF ACERE 2018). In coastal regions, these impacts extend to estuarine and coastal environments, exacerbating the formidable pressures from human activities on coastal ecosystems.

With increasing pressures on urban water systems (hereafter called UWS), and a growing emphasis on sustainable solutions that integrate economic, environmental and social needs, urban water management is undergoing a transition. Water managers are advocating for integrated approaches that link different elements of the urban water cycle, and emphasize the need to break down management silos (Owen 2015; US Water Alliance 2016; Roth and Mazza 2017). For example, wastewater and stormwater can become a resource through water reuse, and flood mitigation can be integrated with urban park and habitat management. These approaches have been called variously "water sensitive cities" (Wong and Brown 2009), "sustainable urban water management" (Marlow et al. 2013), and "One Water" approaches (Mukheibir et al. 2014; US Water Alliance 2016; Bolson et al. 2018).

The City Water Blueprint was developed as a framework to assess the sustainability of urban water management for cities at a global scale (van Leeuwen et al. 2012; Koop and van Leeuwen 2015). City Water Blueprints can help assess vulnerabilities of UWS, distinguish barriers to effective water management solutions and inform policy with the goal of improving water management solutions through integrated planning, i.e., "One Water Solutions". However, translating "One Water
Solutions" into regionally-relevant actions for water managers, and involving the general public to build understanding and support for sustainable water management and planning in their cities requires more than a blueprint. Region and locationspecific approaches are needed to 1) engage diverse water managers to help identify key concerns and develop locally-relevant, cross-scale solutions, 2) identify important system attributes and responses and 3) quantify those responses under alternative future management and climate scenarios.

Future planning for managing UWS requires not only the ability to assess existing systems but also methods to imagine, design, and evaluate the response of innovative UWS that anticipate coming change. To be most effective, planning and modeling approaches must include not only conventional practices and infrastructure, but also innovative water management options and new types of infrastructure that conceive natural and constructed parts of water systems as an integrated whole (Mitchell 2006; Owen 2015). However, innovative methods for water management pose a challenge to planners and modelers precisely because they are novel (Santelmann et al. 2001). In many regions, we lack existing analogs or long-term data sets needed to model system behavior and effectiveness of a given solution across different contexts and scales. Few studies have assessed the cumulative effects of grey and green infrastructure solutions at the spatial extent of watersheds on the order of 100 to 1000 ha in size (Jefferson et al. 2017) and fewer still have integrated across spatial extents from parcel to watershed to basin. Yet, scale-dependency of impacts and trade-offs among those impacts across different sectors and scales has been identified as a key element of urbanization. Seto et al. (2017) note that "... urban sustainability is inherently multidimensional and multiscalar ... Solutions at one spatial scale or along one dimension (e.g., energy, land use) may not have the same effect at a different spatial scale or dimension. One example of this is the spatial pattern of urban land use, which results in varying trade-offs at different scales".

Urban ecosystems are well-suited to the application of a geodesign conceptual framework (Steinitz 2012), in part because the process requires explicit considerations of scale and context. Geodesign incorporates interdisciplinary perspectives, design across specific geographic scales, and uses GIS-based analytic and design tools to explore alternative future scenarios and their impacts. The geodesign process incorporates six different types of models, including: 1) Decision models, 2) Representation models, 3) Process models, 4) Evaluation models, 5) Change models, and 6) Impact models. Sustainable UWS will require not only innovative design across sectors and scales, but also the use of effective and appropriate models to assess the system response across multiple sectors, dimensions and scales (Steinitz 2012). Because urban ecosystems are complex, and system response must be assessed for multiple systems, the development and implementation of innovative UWS poses major challenges to planners and decision makers. 
These challenges, and an approach to develop the capacity to model whole system responses in meeting them, are identified and discussed here. We group the steps of this approach under three broad categories, as follows:

1. Building Collaborations for the Future: Engagement of stakeholders- envisioning water solutions that are likely to be applied by diverse water managers across whole water systems requires that research teams work with knowledgeable stakeholders to clarify priorities, which often include exploring a variety of integrated policy and technological solutions.

2. Field Testing the Future: Transdisciplinary design of systems - an iterative approach to the design of future scenarios can help water managers, planners and the public explore high priority UWS alternatives and depict them across scales. This process allows combined Researcher/Stakeholder teams to incrementally agree on water system priorities at each scale, and to better understand the linkages among them. Use of an incremental approach allows the time necessary for development of alternative futures that are plausible, acceptable to endusers, and feasible for the research team to evaluate.

3. Simulating the Future: Modeling and evaluation of whole UWS performance requires both data and an array of modeling and evaluative tools that can be used to investigate system response at appropriate spatial and temporal scales. Models must be able to evaluate both current systems and alternative futures at the multiple scales relevant to different end-users.

Multiscale, spatially- and temporally-explicit scenario approaches are powerful methods for working with stakeholders. These approaches can be used to focus attention on key systems of interest, and then illustrate existing conditions and future trajectories in familiar ways, ways compatible with how people actually experience places. Here, we define a spatially-explicit scenario as one that is specific to a place, and linked to georeferenced data that describe the attributes of that place (e.g., topography, land cover, climate, and census data). Scenarios, and the models used to generate representations of these scenarios, are both spatially- and temporally-explicit when they simulate and specify the changes in the spatial attributes of place over specific time frames.

\section{Building collaborations for the future: identifying priorities in transdisciplinary projects}

"Alone we can do so little, together we can do so much." Helen Keller (Lash 1980)
To illustrate our multiscale, multi-sector approach and its application to the challenges inherent in development of innovative UWS, we report here on one part of the national Urban Water Innovation Network or UWIN, a collaborative effort of water stakeholders and researchers from across the U.S.A. (Bolson et al. 2018). The summary that follows uses work from one UWIN study region in the U.S. Pacific Northwest, western Oregon's Willamette River Basin (Fig. 1). We highlight efforts of a joint researcher/stakeholder team that defined priorities for urban water management in this region. Using input from an iterative series of stakeholder/researcher collaborations that took place over the course of two years, the team developed three ca. 2060 mapped alternative futures, shown at three nested spatial extents; the 3 million ha. Willamette River Basin, the 4000 ha Chicken Creek watershed, and the 100 ha. West Sherwood urban neighborhood. The scenarios depicted responses to future pressures and trends that reflected stakeholder priorities and were considered plausible based on their expert knowledge.

The stakeholder group included representatives of city, county, and state governments, citizens, coalitions, nonprofits and businesses. Members volunteered their time. They were selected based on a combination of professional affiliation and demonstrated expertise in four important water sectors (Table 1), as well as interest in exploring new ideas and sustainability. We purposely sought to engage members who had demonstrated leadership in the various water sectors, and were willing to assist the research team in vetting indicators of water sustainability.

The earliest engagements with the Oregon stakeholder group occurred as part of a series of national meetings intended to clarify regional similarities and differences in water management challenges across the U.S.A. During regional meetings, data were collected through pre- and post-meeting surveys and observations of open-ended discussions to identify stakeholder perspectives on key urban water challenges, drivers and pressures propelling these challenges, and promising solutions (Bolson et al. 2018).

Bolson et al. (2018) identified common concerns among water managers across the country, but also highlighted regional differences (Table 2). For example, climate change and ecosystem degradation were frequently cited challenges across regions, but the specifics of those concerns differed. Concerns about climate change in the Florida stakeholders centered around risks and impacts associated with sea level rise, while concerns in the Pacific Northwest focused on reduced water availability during hotter, drier summers and competing demands from a growing population. Ideas on how to overcome those perceived challenges varied by region. Among the Pacific Northwest stakeholders, there was strong interest in collaborative planning and looking for win-win opportunities where a single project would derive multiple benefits for diverse sectors or groups. There was also a desire 


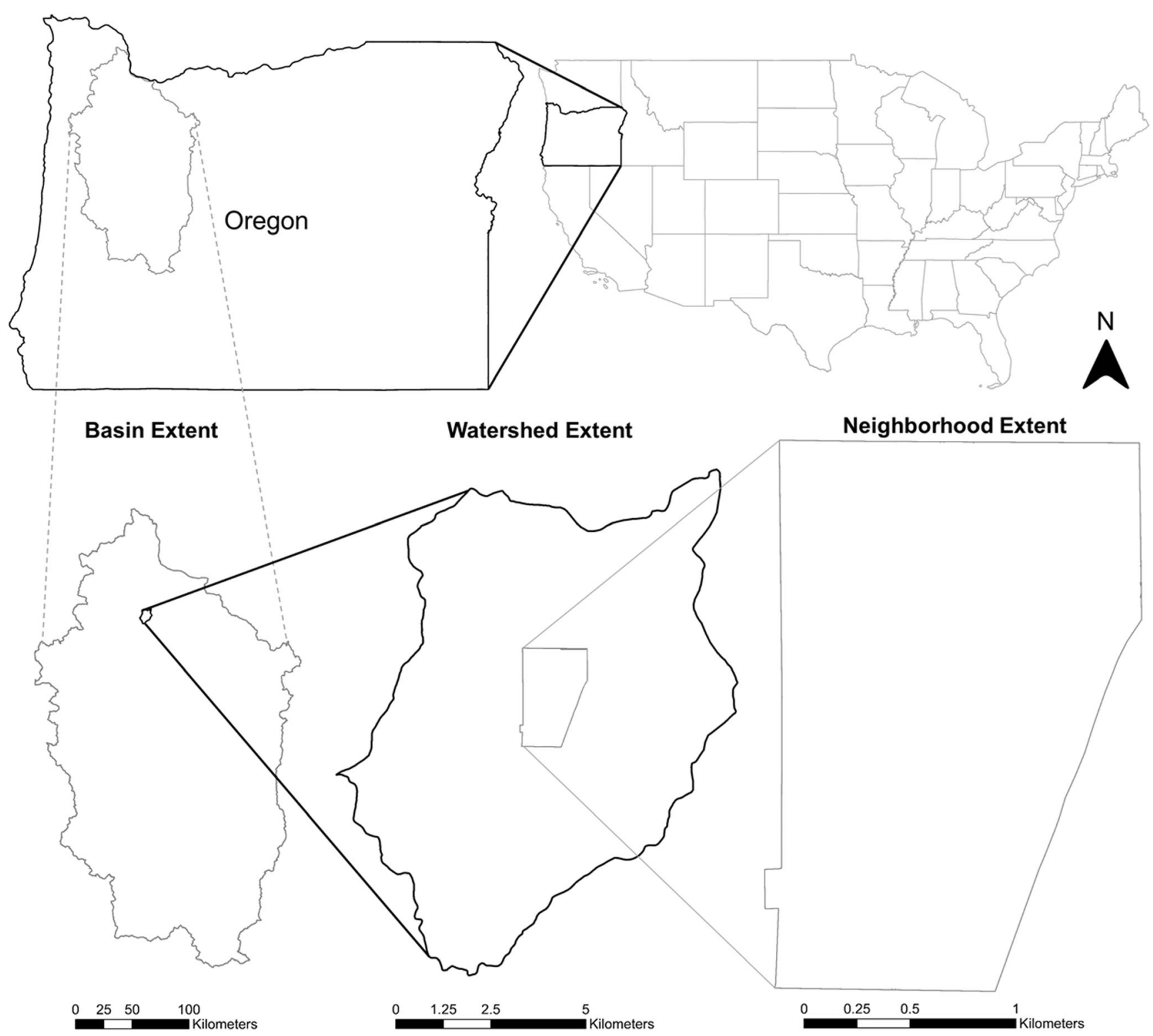

Fig. 1 Context Map of Willamette River Basin within U.S.A. and Oregon; showing spatial extent of the nested study regions; Willamette River Basin, Chicken Creek Watershed, and Sherwood Focal Neighborhood

to think across spatial scales. For example, stormwater managers advocated for exurban riparian protection as a costeffective way to reduce thermal loads before streamflow entered developed areas, and water providers placed water availability in the context of water needs for agriculture and endangered fish.

Following the initial meetings that contributed to the national survey, we held a series of quarterly Oregon researcher/ stakeholder meetings, each lasting approximately three hours. These meetings were dedicated to more detailed discussions of scenario design, leading to spatially- and temporallyexplicit depictions of plausible alternative futures. In the sections that follow, we highlight key qualities of the alternative futures developed in this collaborative process, and summarize them in Table 3.
Field testing the future: Designing innovative, multi-scale alternative futures

"Premier among the consequences of being human is the capacity to imagine possible futures, and to plan and choose among them."

E. O. Wilson (2014)

Scenario-driven alternative futures analysis is an approach to anticipatory assessments designed to inform community decisions about the likely effects of different options for future land and water use (Santelmann et al. 2001; Hulse et al. 2004; Liu et al. 2007; Mahmoud et al. 2009; Steinitz 2012; Wu et al. 2015, Rastandeh 2015). The primary advantage of this approach is as an integrative procedure for 
Table 1 Key system requirements and goals for the four urban water sectors, and the opportunities that could be provided by integration across sectors

Sector Overarching system goals $\quad$ Key elements of a well-performing system Opportunities provided by integration

Drinking water Public health; adequate water supply for population, reliable system of treatment and delivery

Stormwater

Public and ecosystem health; protection from localized flooding, reduced pollution from non-point sources

Wastewater

Public and ecosystem health; removal and treatment of human and industrial wastewater prior to release into natural waterbodies

Natural waterbodies (riparian zones)

Public and ecosystem health; protect communities from flooding,
Adequate source water protection, treatment facilities, distribution network

Capacity to meet future demands (resilient to climate change, population change)

Infrastructure and source resilient to disruption from natural disasters/other emergencies

Efficient (minimal water loss through leaks; minimal energy use)

Meets social needs in a just and equitable manner

Conveys water away from buildings and infrastructure

Prevents flooding, even during low frequency, extreme events

Minimizes water quality/quantity impacts of stormwater runoff on riparian areas and water bodies

Conveys sewage and waste away from dwellings/infrastructure

Recycles sewage solids

Minimizes water quality/quantity impacts of discharge to surface water (ideally with secondary and/or tertiary treatment)

Minimizes combined sewer overflows

Capacity to meet future demands (population change)

Efficient

Resilient to disruption from natural disasters/other emergencies

Meets social needs in a just and equitable manner minimize development impacts on riparian areas and water bodies
Community planning accounts for flood risks

Maintains wetlands/riparian areas to provide habitat, mitigate flood risks

Manages sediment regime/hydrology to minimize impact on stream habitat, and water quality
Stormwater or wastewater reuse lower water supply needs, and could reduce treatment and conveyance costs and minimize ecosystem impacts of withdrawals and infrastructure

Effective treatment of stormwater improves water quality and function of natural streams/other water bodies

Storm water becomes a resource in a "fit-for-purpose" reuse or for groundwater recharge

Some components of wastewater can become resources (e.g., struvite as fertilizer)

Grey water put to "fit-for-purpose" reuse

Reducing wastewater volumes could reduce treatment costs or provide added capacity for population growth

Tertiary treatment areas (e.g. wetlands) provide recreational/ecological benefits

Protected riparian zones provide for co-benefits such as reducing the urban heat island effect, providing wildlife habitat, or tertiary treatment of wastewater and stormwater connecting the different ways of understanding the processes that shape landscapes. These range from the biophysical processes in the disciplinary realm of the sciences and engineering to the social policy and management decisions that influence land and water use. While the specific characteristics of scenario-driven alternative future studies are as diverse as the situations in which they are applied, common qualities arise. These studies begin by defining discrete, coherent assumptions about how conditions of interest unfold in some bounded place over some specified period of time. A logically coherent group of these assumptions comprise a scenario (Wodak and Neale 2015; IPBES 2016). For many scenario studies it suffices to represent scenarios with narrative descriptions alone, but, in our usage, a spatially-explicit representation of a scenario's land and water use at temporally-explicit time steps comprise an alternative future.

The next step in scenario-driven alternative future studies subjects these alternative future representations to a series of computational evaluation models to learn what effects each alternative future may have on some defined set of system responses. Continued collaboration with stakeholders helps focus this evaluation on the elements of the system that people care about. This evaluative phase is often of prominent concern to stakeholders, because it allows them to compare and contrast the modeled implications of choosing one alternative over another. Where the focus is on anticipating trajectories of change caused by human use of land and water, scenario-driven approaches provide a framework for effectively incorporating science into community-based decision- 
Table 2 Summary of national and region-specific challenges and solutions for urban water management identified by national UWIN stakeholder meetings (Bolson et al. 2018). National themes gain specificity when considered in a regional context

\begin{tabular}{|c|c|c|c|}
\hline \multicolumn{2}{|c|}{ Water system challenges and barriers to integrated solutions } & \multicolumn{2}{|l|}{ Potential solutions } \\
\hline National UWIN Themes & PNW UWIN Themes & National UWIN Themes & PNW UWIN Themes \\
\hline $\begin{array}{l}\text { Climate change } \\
\text { Water supply reliability } \\
\text { Population change }\end{array}$ & $\begin{array}{l}\text { Hotter drier summers = greater demand, } \\
\text { reduced supply } \\
\text { Growth of urban areas footprint/intensity } \\
\text { Wildfire in source water areas } \\
\text { Competing summer water demands - } \\
\text { instream needs for endangered fish, } \\
\text { agriculture, growing cities }\end{array}$ & $\begin{array}{l}\text { Increase social/human capital } \\
\text { (including behavioral and } \\
\text { institutional change) }\end{array}$ & $\begin{array}{l}\text { Behavioral conservation advances } \\
\text { (public education) } \\
\text { Tools to inform public about } \\
\text { conservation } \\
\text { Changes to allocation of stored water } \\
\text { in the Willamette Project (federal } \\
\text { reservoir system) }\end{array}$ \\
\hline $\begin{array}{l}\text { Water quality concerns } \\
\text { Natural systems }\end{array}$ & $\begin{array}{l}\text { Habitat degradation (nutrients, toxics, } \\
\text { thermal pollution) } \\
\text { Regulatory requirements } \\
\text { Groundwater overdraft }\end{array}$ & & $\begin{array}{l}\text { Regional cooperation - "One Water" } \\
\text { mindset } \\
\text { Collaboration around development } \\
\text { and decision making across sectors } \\
\text { Integrated planning and sophisticated } \\
\text { information to inform decisions }\end{array}$ \\
\hline Institutional challenges & $\begin{array}{l}\text { Multiple jurisdictions, multiple regulatory } \\
\text { authorities, intersecting laws } \\
\text { Lack of incentives for collaboration } \\
\text { Complicated water rights }\end{array}$ & $\begin{array}{l}\text { Implement decentralized } \\
\text { solutions }\end{array}$ & $\begin{array}{l}\text { Technological conservation (smart } \\
\text { irrigation controllers, toilet } \\
\text { rebates, fix leaks) }\end{array}$ \\
\hline Knowledge limitations & $\begin{array}{l}\text { Lack of acceptance of water efficiency } \\
\text { Water management taken for granted } \\
\text { Uncertainty about future }\end{array}$ & Increase natural capital & $\begin{array}{l}\text { Green infrastructure - integrating } \\
\text { urban and natural systems for } \\
\text { multiple benefits }\end{array}$ \\
\hline Economics (funding) & $\begin{array}{l}\text { Rate concerns, lack of public awareness on } \\
\text { water systems, limited willingness to pay } \\
\text { Lack of funds for education, especially small } \\
\text { water providers } \\
\text { Competing demands for limited funding } \\
\text { Speculative activity on water (new ag users) }\end{array}$ & Increase financial capital & $\begin{array}{l}\text { Opportunistic collaboration across } \\
\text { sectors and between cities and } \\
\text { exurban upstream watershed } \\
\text { protection } \\
\text { Water quality trading }\end{array}$ \\
\hline $\begin{array}{l}\text { Technology needs } \\
\text { Infrastructure }\end{array}$ & $\begin{array}{l}\text { Age of infrastructure, lack of funds for } \\
\text { maintenance, backlog of defined } \\
\text { maintenance, leaks } \\
\text { Energy use associated with moving water } \\
\text { between multiple disconnected systems }\end{array}$ & $\begin{array}{l}\text { Implement centralized solutions } \\
\text { (manmade capital) }\end{array}$ & $\begin{array}{l}\text { Water reuse } \\
\text { Increase environmentally sensitive } \\
\quad \text { water storage alternatives }\end{array}$ \\
\hline Hazards & $\begin{array}{l}\text { Seismic preparedness } \\
\text { Security } \\
\text { Development in riparian areas }\end{array}$ & & \\
\hline
\end{tabular}

making and, in the process, for fostering a more sophisticated dialogue of the facts, values and perceptions that underpin informed land and water management. And when this is done well, E.O. Wilson argues, it allows us to 'field test the future'.

\section{Defining the roles of stakeholders and experts}

Where innovation is a motivating purpose of scenariodriven alternative futures projects, especially innovation concerning complex systems such as those needed to protect, provide and treat urban water, there is a central need for engagement of both knowledgeable stakeholders and scientific experts. Such transdisciplinary engagement has inevitable transaction costs (Mahmoud et al. 2009; Musacchio 2009). One source of high transaction costs are the different ways of thinking and working prevalent among professionally-diverse project participants, and the varying incentive systems in their professional lives that motivate them to know a little about a lot, or a lot about a little (Ferguson et al. 2016).

In the case of urban water innovations, there are often trade-offs between a participant's a) technical expertise, b) degree of familiarity with the various sectors and systems (e.g. drinking water, stormwater, wastewater, natural waterbodies) and associated rate payer and user feedriven business models that may fund these sectors, as well as c) imaginative capacity to conceive truly innovative futures (Steinitz 2012). It can be difficult for those who know existing systems well to imagine a radically different future, that is, to think beyond what they have personally known and experienced (Baker et al. 2004; Hulse et al. 2016). As a result, a central challenge when designing and modeling alternative urban water futures is to ensure that both alternative futures and evaluative models bracket 
Table 3 Multi-scale alternative future scenario assumption matrix. Working with a regionally representative group of stakeholders, researchers clarify assumptions about key concerns that distinguish plausible, water-relevant scenarios at river basin $(\sim 30,000 \mathrm{~km} 2)$, watershed ( $\sim 4000 \mathrm{ha})$ and neighborhood ( 100 ha) spatial extents, all with a ca. 2060 planning horizon

\begin{tabular}{|c|c|c|}
\hline & Current Course ca. 2060 & Stressed Resources ca. 2060 \\
\hline Scenario theme & $\begin{array}{l}\text { Current regulatory regime remains } \\
\text { in force. }\end{array}$ & $\begin{array}{l}\text { Water treatment and conveyance systems } \\
\text { are stressed. }\end{array}$ \\
\hline \multicolumn{3}{|l|}{ Pressures \& Trends } \\
\hline Climate $^{\mathrm{i}}$ & $\begin{array}{l}\text { Midrange of climate change } \\
\text { projections; } 2.5^{\circ} \mathrm{C} \text { increase in } \\
\text { annual mean temperature } \\
\text { (MIROC5 RCP8.5) }\end{array}$ & $\begin{array}{l}\text { High end of climate change projections; } \\
4.0^{\circ} \mathrm{C} \text { increase in annual mean } \\
\text { temperature (HadGEM2-ES RCP8.5) }\end{array}$ \\
\hline Population growth ${ }^{\mathrm{i}}$ & $\begin{array}{l}\text { Midrange population increase; } \\
\text { Willamette Basin } 2060 \\
\text { population is } 4.5 \mathrm{M} \text { (from } 2.4 \mathrm{M} \\
\text { in 2010) }\end{array}$ & $\begin{array}{l}\text { High population increase; Willamette } \\
\text { Basin } 2060 \text { population is } 6.2 \mathrm{M} ; 37 \% \\
\text { increase relative to Current Course }\end{array}$ \\
\hline Key Concerns & \multicolumn{2}{|c|}{ Basin Extent - Scenario Assumptions (Willamette River Basin) } \\
\hline Wildfire suppression & $\begin{array}{l}\text { Wildfire suppression at historical } \\
\text { rates; forest area burned averages } \\
0.5 \% \text { of forested area in basin per } \\
\text { year over the modeled period. }\end{array}$ & $\begin{array}{l}\text { Increase in wildfire suppression so that } \\
\text { forest area burned averages } 1.4 \% \text { of } \\
\text { forested area in basin per year over the } \\
\text { modeled period. }\end{array}$ \\
\hline $\begin{array}{l}\text { Agricultural water } \\
\text { demand }\end{array}$ & $\begin{array}{l}\text { Crop mixes similar to } 2010 \text {; crop } \\
\text { and energy prices do not rise in } \\
\text { real terms; result is about } \\
111,000 \text { ha irrigated. Average } \\
\text { fraction of water rights used in a } \\
\text { given year is } 2 / 3 \text { of existing } \\
\text { irrigation water rights. }\end{array}$ & $\begin{array}{l}\text { New irrigation contracts and related } \\
\text { rights introduced } 2015-2044 \text {. } \\
\text { Conveyance costs decrease through } \\
\text { efficiencies; water contract fees set to } \\
\text { zero; crop choice as in Current Course. } \\
\text { Average fraction of water rights used } \\
\text { in a given year is } 5 / 6 \text { of existing } \\
\text { irrigation water rights. }\end{array}$ \\
\hline $\begin{array}{l}\text { Reservoir } \\
\text { management }\end{array}$ & $\begin{array}{l}\text { Rule curves implemented as of } \\
\text { 2011; reservoir refill begins } \\
\text { Feb } 1 \text { with target to fill reservoirs } \\
\text { by May. No new water rights and } \\
\text { no new deliveries of stored water } \\
\text { from reservoirs. }\end{array}$ & $\begin{array}{l}\text { Reservoir refill begins March 1, ramps } \\
\text { up to existing rule curves between } \\
\text { March and May; } 2 \% \text { chance each year } \\
\text { for one of the five biggest reservoirs to } \\
\text { go offline for one calendar year; } \\
\text { reservoir treated as "Run of the River" } \\
\text { when offline. New claims of stored } \\
\text { water (May-October) up to } 197 \mathrm{M} \\
\text { cubic meters for municipal uses, up to } \\
404 \mathrm{M} \text { cubic meters for agricultural } \\
\text { irrigation. }\end{array}$ \\
\hline
\end{tabular}

Integrated Water Future ca. 2060

Water quality and quantity are managed at the watershed extent.

High end of climate change projections; $4.0{ }^{\circ} \mathrm{C}$ increase in annual mean temperature (HadGEM2-ES RCP8.5)

High population increase; Willamette Basin 2060 pop is $6.2 \mathrm{M}$; $37 \%$ increase relative to Current Course

Change forest management to reduce wildfire, thus increasing wildfire suppression, so that forest area burned averages $0.95 \%$ of forested area in basin over the modeled period.

New irrigation contracts and related rights introduced 2015-2044. Conveyance costs decrease through efficiencies; contract fees set to zero; crop choice as in Current Course. Average fraction of water rights used in a given year is $2 / 3$ of existing irrigation water rights.

Reservoir refill begins March 1, ramps up to existing rule curves between March and May. New claims of stored water (May-October) up to $197 \mathrm{M}$ cubic meters for municipal uses, up to $404 \mathrm{M}$ cubic meters for agricultural irrigation.

\section{Key Concerns \\ Healthy streams; Flood protection}

\begin{abstract}
Watershed Extent - Scenario
Current practices and policies continue.
\end{abstract}

\section{Management of riparian zones and watershed land management}

Role of stormwater reclamation \& reuse
Within urbanized areas, width of protected riparian zones current policies and development patterns. In newly urbanizing and designated rural areas, METRO regional government guidelines for riparian protection zones apply.

BMPs are used in MS4 areas and include water reuse. Downspouts disconnection allows $80 \%$ of
Development occurs in riparian areas that are protected in the Integrated Water future. Ten percent of METRO-designated riparian protection zones are developed.

Storm water management relies more on grey infrastructure than is the case in Current Course.
Because storm water management relies more on green infrastructure than Current Course, pervious surface is increased relative to Current Course. Subsidies encourage higher home densities and reduced building footprints, reducing area of impervious surface.

All riparian corridors are protected. Floodplain reconnection and large GI features created where topography and soils are appropriate. Rural land is purchased prior to inclusion in urban growth areas. Base flows and channel forming flows are maintained at adequate volumes.

Storm water is more commonly reclaimed and reused in newly urbanized territory, thereby reducing 
Table 3 (continued)

\begin{tabular}{|c|c|c|c|}
\hline & $\begin{array}{l}\text { storm water to be infiltrated on } \\
\text { site. }\end{array}$ & & $\begin{array}{l}\text { water demand on other systems. } 100 \% \\
\text { of stormwater is captured on-site. }\end{array}$ \\
\hline $\begin{array}{l}\text { Water conservation } \\
\& \text { reuse }\end{array}$ & $\begin{array}{l}50 \% \text { of households are high } \\
\text { efficiency indoor water users } \\
\text { (424 1 per household per day); } \\
50 \% \text { of households are moderate } \\
\text { efficiency ( } 522 \text { lphd). Moderate } \\
\text { adoption of xeriscaping and high } \\
\text { efficiency irrigation systems. } \\
\text { Greywater is not reused. }\end{array}$ & $\begin{array}{l}100 \% \text { of households are moderate } \\
\text { efficiency indoor water users ( } 522 \\
\text { lphd). Outdoor water conservation } \\
\text { practices remain unchanged since } \\
\text { 2010. Greywater is not reused. } \\
\text { Stormwater is not reused. }\end{array}$ & $\begin{array}{l}90 \% \text { of households are high efficiency } \\
\text { indoor water users ( } 424 \text { lphd); } 10 \% \text { of } \\
\text { households are moderate efficiency } \\
\text { (522 lphd). Aggressive adoption of } \\
\text { xeriscaping and high efficiency } \\
\text { irrigation systems. Moderate adoption } \\
\text { of graywater reuse for toilet flushing } \\
\text { with } 7571 \text { per household ( } 200 \text { gph) } \\
\text { storage. Aggressive adoption of } \\
\text { stormwater capture and reuse for } \\
\text { irrigation with } 11,3561 \text { per household } \\
\text { (3000 gph) storage. }\end{array}$ \\
\hline $\begin{array}{l}\text { Number of } \\
\text { households }\end{array}$ & $\begin{array}{l}3629 \text { new households are added by } \\
\text { ca. } 2060,1218 \text { in the Sherwood } \\
\text { Neighborhood and } 2411 \text { outside } \\
\text { of it, in addition to } 84 \text { new rural } \\
\text { dwellings. }\end{array}$ & $\begin{array}{l}6107 \text { new households are added by ca. } \\
2060,1610 \text { in the Sherwood } \\
\text { Neighborhood and } 4497 \text { outside of it, } \\
\text { in addition to } 115 \text { new rural dwellings. }\end{array}$ & $\begin{array}{l}5919 \text { new households are added by ca. } \\
2060,1494 \text { in the Sherwood } \\
\text { Neighborhood and } 4425 \text { outside of it. } \\
\text { Approximately } 115 \text { rural dwellings are } \\
\text { added, with } 15 \% \text { in clustered } \\
\text { configurations. }\end{array}$ \\
\hline Key Concerns & \multicolumn{3}{|c|}{ Neighborhood Extent - Scenario Assumptions (Sherwood Neighborhood Focal Area) } \\
\hline $\begin{array}{l}\text { Stormwater } \\
\text { management; } \\
\text { green } \\
\text { infrastructure (GI) }\end{array}$ & $\begin{array}{l}32 \text { ha of GI in the Sherwood } \\
\text { Neighborhood focal area by ca. } \\
2060,28 \% \text { of area. GI facilities } \\
\text { employed only within urbanized } \\
\text { territory. }\end{array}$ & $\begin{array}{l}16 \text { ha of GI in the Sherwood } \\
\text { Neighborhood focal area by ca. } 2060 \text {, } \\
14 \% \text { of area, no new GI facilities } \\
\text { installed after } 2030 \text {. GI facilities } \\
\text { employed only within urbanized } \\
\text { territory. }\end{array}$ & $\begin{array}{l}55 \text { ha of GI in the Sherwood } \\
\text { Neighborhood focal area by ca. } 2060 \text {, } \\
48 \% \text { of area. BMPs extend beyond } \\
\text { neighborhoods under development } \\
\text { and are integrated with watershed } \\
\text { management systems. }\end{array}$ \\
\hline $\begin{array}{l}\text { Number of } \\
\text { households; } \\
\text { residential density }\end{array}$ & $\begin{array}{l}1218 \text { households sited avoiding } \\
\text { narrow riparian lands and steep } \\
\text { slopes. Total impervious } \\
\text { cover }=63 \% \text {. }\end{array}$ & $\begin{array}{l}1610 \text { households sited avoiding narrow } \\
\text { riparian lands and steep slopes. Total } \\
\text { impervious cover }=72 \% \text {. }\end{array}$ & $\begin{array}{l}1494 \text { households sited at higher density } \\
\text { than in Current Course, avoiding all } \\
\text { riparian lands, steep, and forested } \\
\text { lands. Total impervious cover }=55 \% \text {. }\end{array}$ \\
\hline
\end{tabular}

${ }^{\mathrm{i}}$ Climate and population assumptions as in Jaeger et al. (2017); MIROC5 and HadGEM2-ES are general circulation models used to model global climate; GI = green infrastructure; $\mathrm{BMP}$ = best management practice; $\mathrm{MS} 4$ = municipal separate sanitary and stormwater system

innovative practices, and that they do not unduly constrain options and choices for future UWS.

\section{Highlights of the Willamette River Basin alternative futures effort}

The Willamette River Basin is the Pacific Northwest case study area of the national UWIN project. As was the case across all the national UWIN study areas, Oregon stakeholders (called the Stakeholder Advisory Committee (SAC)) concluded that climate change and population growth were key pressures and trends for the future (Bolson et al. 2018). Because so many biophysical processes that effect water are driven by climate forcings, the research team built on prior work in the Willamette Basin (Hulse et al. 2016; Jaeger et al. 2017) and recommended using future climate assumptions from spatially-downscaled regional outputs of atmosphere-ocean general circulation models (GCM) in combination with Representative Concentration Pathways (RCP) that integrate emissions concentrations, land-use change and socio-economic responses. For this effort we selected two GCM x RCP combinations representing medium and high impacts on vegetation, evapotranspiration and wildfire at the spatial extent of the Willamette Basin. The chosen climate models from which these assumptions were derived have been shown to perform well in replicating the historical climate of the U.S. Pacific Northwest (Rupp et al. 2013).

Population and future housing need assumptions were derived from state-sanctioned projections at the county level for the river basin extent (Jaeger et al. 2017), augmented with transportation planning population projections for the watershed extent (City of Sherwood 2014) and local preliminary growth concept plans at the neighborhood extent (City of Sherwood 2016a). Use of local population and housing projections for local spatial extents, in tandem with coarser-extent population projections from state-level sources, proved important in convincing stakeholders that projections were sufficiently realistic and responsive to local constraints to merit consideration.

With future climate and population assumptions agreed, the Research Team worked iteratively with the stakeholders over 
two years to depict three 2060 alternative futures at each of three spatial extents - basin, watershed and neighborhood. The watershed ( $\sim 4000 \mathrm{ha})$ and neighborhood ( $100 \mathrm{ha})$ extents and locations were identified jointly with the stakeholders over a series of meetings as a consensus emerged regarding key water concerns and the spatial grains and extents at which alternative futures addressing these concerns would need to be explored and depicted. The three futures were named: Current Course ca. 2060, Stressed Resources ca. 2060 and Integrated Water Future ca. 2060, each corresponding to a central organizing scenario theme. In Current Course ca. 2060, the theme is that the current land and water regulatory regime is assumed to remain in force through 2060. In Stressed Resources ca. 2060, water treatment and conveyance systems are assumed to be stressed as a result of the combined pressures of population growth, changing climate, and policies that respond to, but do not anticipate the need for change. In Integrated Water Future ca. 2060, water quality and quantity management are assumed to be coordinated at the watershed extent in ways that incorporate innovation and anticipate future pressures. Reduced to its essentials, the process of working with the stakeholders began with 1) agreeing on overarching scenario themes and then progressively clarifying scenario assumptions for the same set of key concerns for each future at basin, watershed and neighborhood extents; then 2) iteratively presenting, discussing and revising, based on stakeholder guidance, the mapped spatial patterns of land use and land cover at each spatial extent. The futures were deemed complete once a consensus was reached among the stakeholders that the mapped patterns adequately represented the stated assumptions regarding each concern.

The key concerns are noted in the left column of Table 3. Definition of assumptions for each key concern progressed from general concepts, such as the assumed degree of future coordination across discrete water management sectors, to agreeing on parameter values (e.g. number of new households), to detailed spatial allocations (e.g. where should new homes be sited) based on local conditions. The focus in this portion of the effort was on producing depictions of land and water use that, in the judgement of the combined stakeholder/researcher team, were consistent with the stated assumptions for each key concern of

\section{Chicken Creek Watershed}
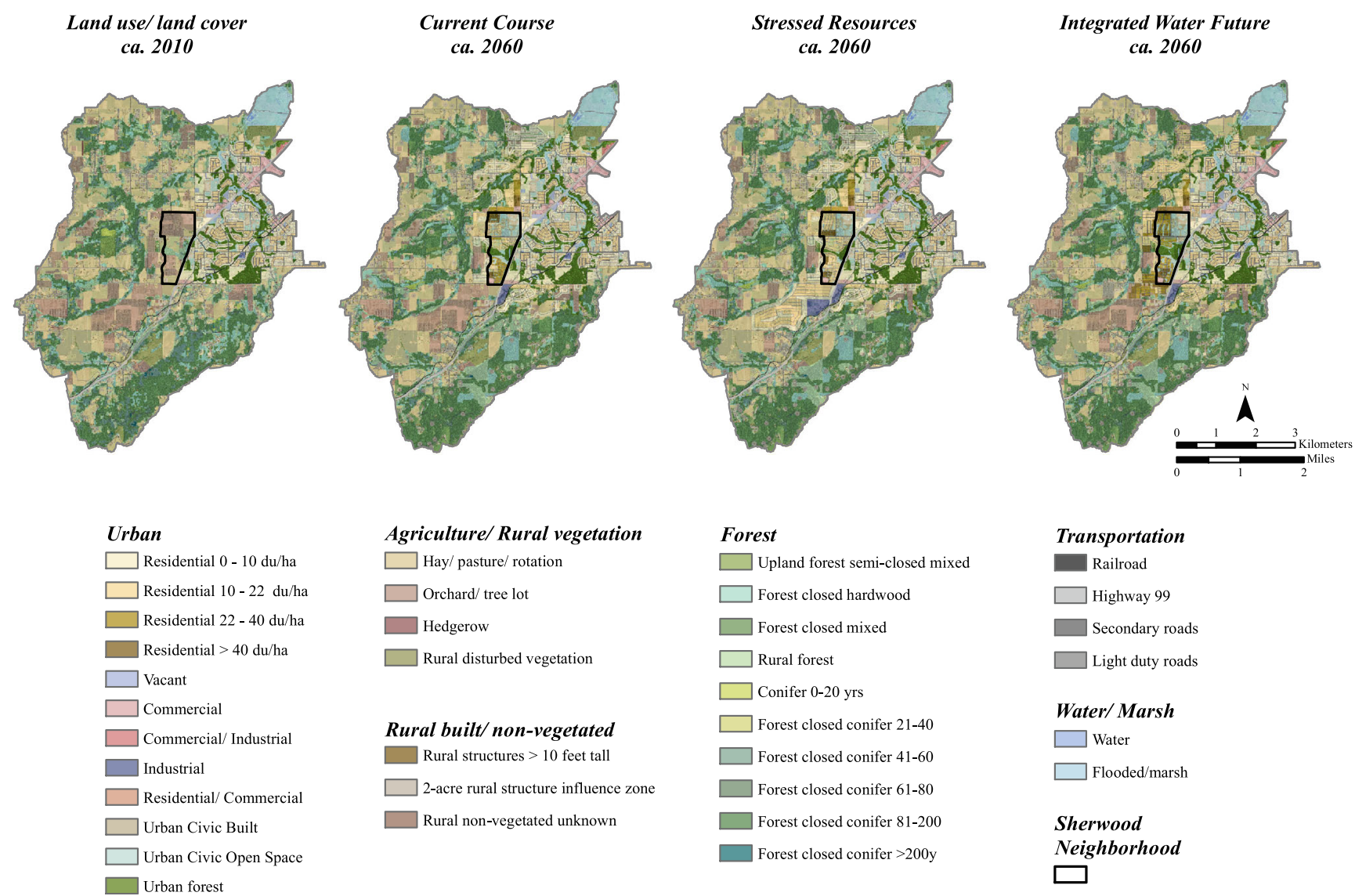

Fig. 2 Land use and land cover depictions at the Chicken Creek Watershed spatial extent for the existing (circa 2010) and three alternative future landscapes (circa 2060) 

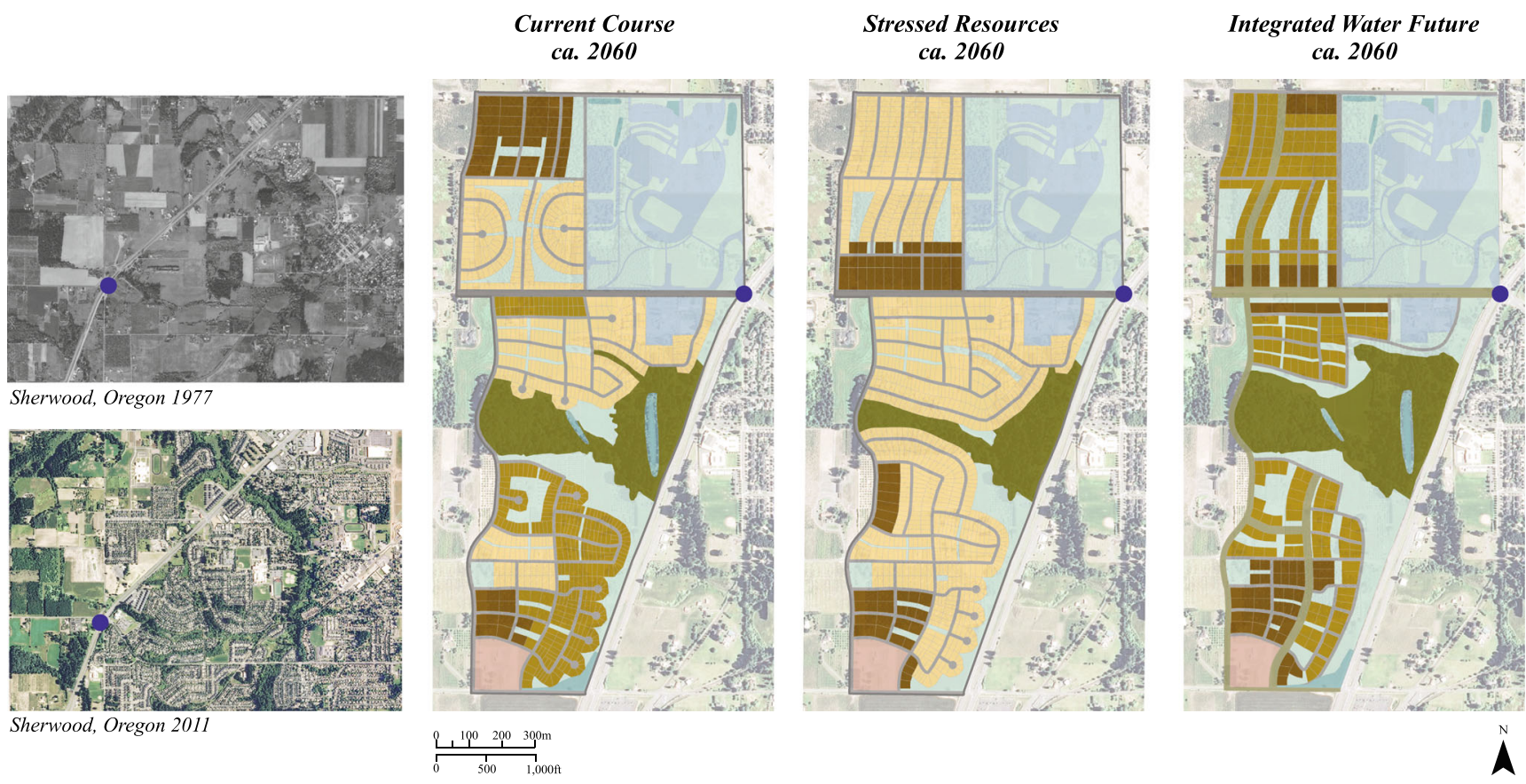

Ca. 2060 Land use/land cover
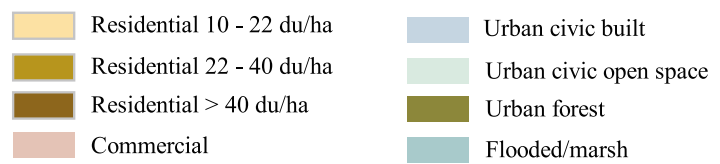

Light Duty Roads

Secondary roads

Fig. 3 Historic air photo comparison of Sherwood area in 1977 (top left), and 2011 (lower left); and three ca. 2060 alternative future land use and land cover depictions at the Sherwood Focal Neighborhood spatial extent

each alternative future scenario at each extent. These scenario assumptions are listed in the body of Table 3 and, for illustration, the corresponding mapped patterns for watershed and neighborhood extents are shown in Figs. 2 and 3, respectively.

We next offer a description of the study area, briefly characterizing each spatial extent. The Willamette River Basin contains about $12 \%$ of the land area of Oregon, is home to over $69 \%$ of the state's population and is more than $60 \%$ forested. Forests occur predominantly in the higher elevation montane area. These upland forests evolved in a firedependent natural disturbance regime. The spatial extent of these forests and their rates of evapotranspiration are important factors in the basin's water budget (Turner et al. 2017). The Mediterranean climate is typified by cool, wet winters and warm, dry summers. Summer rainfall makes up $<5 \%$ of the annual average total of $1370 \mathrm{~mm}$, which ranges from $950 \mathrm{~mm}$ to more than $2000 \mathrm{~mm}$ across the basin. The combination of warm summers, ample spring moisture and fertile volcanic soils supports significant agricultural production within the valley, estimated by the Oregon State University
Extension Service (Sorte and Rahe 2015) as influencing more than $13 \%$ of sales of products and jobs in the state.

The Chicken Creek Watershed spans the southwest edge of Portland Metro's Urban Growth Boundary (UGB) (Fig. 1). Although the majority of the watershed is currently outside of Portland's UGB, $60 \%$ of the City of Sherwood, which is inside the UGB, lies within the Chicken Creek Watershed. Portland has identified an Urban Reserve area, called the West Sherwood Urban Reserve, adjacent to the City of Sherwood within the Chicken Creek Watershed. Urban Reserves are an adopted regional growth management device which delimits a bounded territory outside the current UGB showing land designated to accommodate all urban growth for the next 50 years. At present, the primary land uses within the Chicken Creek watershed that are outside of the urbanized City of Sherwood but inside the Urban Reserve are in agricultural and rural residential uses. As of 2010 , approximately $40 \%$ of the watershed was forested land cover.

The Sherwood Focal Neighborhood, as yet unurbanized, is adjacent to the western edge of the Sherwood UGB in the 
West Sherwood Urban Reserve. In 2010, the primary land uses in the Sherwood Focal Neighborhood were agriculture and rural residential. The City of Sherwood has already planned and sited (although not yet constructed) a new high school in the northeast corner of the neighborhood. Stakeholders requested that this high school be incorporated into the alternative futures for all three circa. 2060 Sherwood focal neighborhood futures.

\section{The alternative futures}

We next briefly describe the three alternative futures, focusing here on the watershed and neighborhood extents because of the heightened attention stakeholders devoted to them. The watershed and neighborhood spatial extents are where, in the inherited land tenure system, people and organizations own and manage land and actively alter land use and land cover in areas they control. Prior Willamette Basin efforts and stakeholder experience had previously produced a well-developed basis for scenarios at the basin extent (Hulse et al. 2002, 2009, 2016; Baker et al. 2004; Wu et al. 2015; Jaeger et al. 2017). Of particular note here are the logical and spatial intersections of i) the mapped representations of changes that impact water when lands are converted from nonurban to urban uses, ii) the mapped locations where these impacts affect more than one major water management sector (Table 1), and iii) the capacity of evaluative models to defensibly detect these impacts across scales as portions of the landscape change from nonurban to urban use. By way of reminder, an alternative future consists of a spatial arrangement at a particular time of land use and land cover types in mapped representations in which locations are associated with site attributes at a specific time. This arrangement represents scenario assumptions in spatially explicit (i.e. a neighborhood, a watershed) and temporally explicit (i.e. ca. 2060) form. Regardless of the ways stakeholders may wish to conceive futures, or the ways researchers may wish to evaluate them, the conversation, depiction and evaluation occurs largely through a vocabulary of mapped classes of land use and land cover at discrete spatial extents and time steps, a vocabulary that necessarily constrains evaluative models, since it is primarily the depiction of landscape conditions in space and time that the models evaluate.

\section{Current course ca. 2060}

The Current Course ca. 2060 scenario assumes a continuation of current trends in population, climate change and land use patterns. At the Willamette River Basin extent, the population reaches 4.51 million by 2060 and the average annual temperature is $2.5^{\circ} \mathrm{C}$. higher than the $1950-2005$ average. These underlying assumptions and guidance from stakeholders resulted in expanded residential and road patterns consistent with the ca. 2010 landscape of the already developed adjacent neighborhood of Sherwood - i.e. single family detached homes and a road network to accommodate private vehicle access to each tax lot. The Current Course ca. 2060 Sherwood Neighborhood accommodates 1218 new dwellings (36\% of these dwellings at a residential density of $0-10$ dwelling units per hectare (du/ha), $28 \%$ at a density of $23-40 \mathrm{du} / \mathrm{ha}$ and $36 \%$ at a density of $>40 \mathrm{du} / \mathrm{ha}$ ), resulting in $63 \%$ of the neighborhood area in impervious cover. This number and mix of residential dwelling densities allowed creation of 32 ha of green infrastructure facilities, occupying $28 \%$ of the neighborhood extent, with 12 of these 32 ha in native riparian vegetation.

\section{Stressed resources ca. 2060}

Stressed Resources ca. 2060 assumes a 37\% increase in population over Current Course ca. 2060 (at the Willamette River Basin extent, a total of 6.16 million) and greater increases in average annual temperature (an increase of $4.0^{\circ} \mathrm{C}$ ). The primary assumption in Stressed Resources ca. 2060 is that water treatment and conveyance infrastructure is stressed. More conventional approaches to water management are employed rather than innovations that anticipate the need for flexible response to future change. At the neighborhood extent this means minimum protection of high priority conservation lands (riparian function in particular) and no constraints on the amount of impervious surface. Residential development is still focused on single family detached homes with road networks to accommodate private vehicle ownership. Stressed Resources ca. 2060 accommodates 1610 new dwelling units, $56 \%$ at a density of $0-10 \mathrm{du} / \mathrm{ha}$ and $44 \%$ at a density $>40 \mathrm{du} / \mathrm{ha}$. Accommodating the greater number of dwelling units with more than half again as many single family detached homes $(0-10 \mathrm{du} / \mathrm{ha})$ required a significant increase of dwelling units at the highest density ( $>40 \mathrm{du} / \mathrm{ha}$ ) and resulted in a residential development pattern that occupies a greater percentage of the neighborhood relative to Current Course ca. 2060 , thus increasing impervious cover to $72 \%$ of the neighborhood. This number and mix of residential dwelling densities allowed creation of 16 ha of green infrastructure facilities, occupying $14 \%$ of the neighborhood extent, with 8 of these 16 ha in native riparian vegetation.

\section{Integrated water future ca. 2060}

Integrated Water Future ca. 2060 assumes the same increases in population and average annual temperature as Stressed Resources ca. 2060 (6.16 million people at the Willamette River Basin extent, an average annual temperature increase of $4.0^{\circ} \mathrm{C}$ ). Integrated Water Future ca. 2060 is guided by the 
central organizing principle of coordinated management of water quality and quantity at the watershed extent. Implicit in this scenario is the expectation that innovation will be incorporated into UWS in anticipation of the need for flexibility in the face of future change. At the neighborhood extent this means that protection of watershed riparian function has priority and is considered before the siting of new built features. Integrated Water Future ca. 2060 accommodates 1494 new dwellings, $57 \%$ at a density of $23-40 \mathrm{du} / \mathrm{ha}$ and $43 \%$ at a density of $>40 \mathrm{du} / \mathrm{ha}$, with $55 \%$ of the neighborhood in impervious cover. This number and mix of residential dwelling densities allowed creation of over 55 ha of green infrastructure facilities, occupying $47 \%$ of the neighborhood extent, with 16 of these 55 ha in native riparian vegetation. The primary road network still accommodates private vehicle ownership but Integrated Water Future also incorporates green boulevards that by 2060 have transitioned to focus on alternative modes of transportation (Fig. 4).

Table 4 contrasts selected landscape metrics for the three alternative futures at the watershed and neighborhood extents. Higher density development in the Integrated Water Future Scenario accommodated about $60 \%$ more dwelling units than the Current Course scenario, while maintaining about the same developed land area as Current Course. The emphasis on riparian protection in this scenario also created more habitat for native species, when estimated using a habitat suitability model described by White et al. (1997). In contrast, the emphasis on single family detached homes and limited protection of natural areas, created higher imperviousness and reduced habitat for terrestrial native species in this scenario.

\section{Simulating the future: modeling across scales}

"Creativity of nature and human creativity cannot be separated. But creativity implies surprises: David of Michelangelo or relativity theory. Uncertainty and surprise are part of human destiny."

Ilya Prigogine (2005)

While the national UWIN stakeholder meetings helped identify general stakeholder concerns about the future of urban water management, the subsequent alternative futures process helped the Pacific Northwest stakeholders articulate those
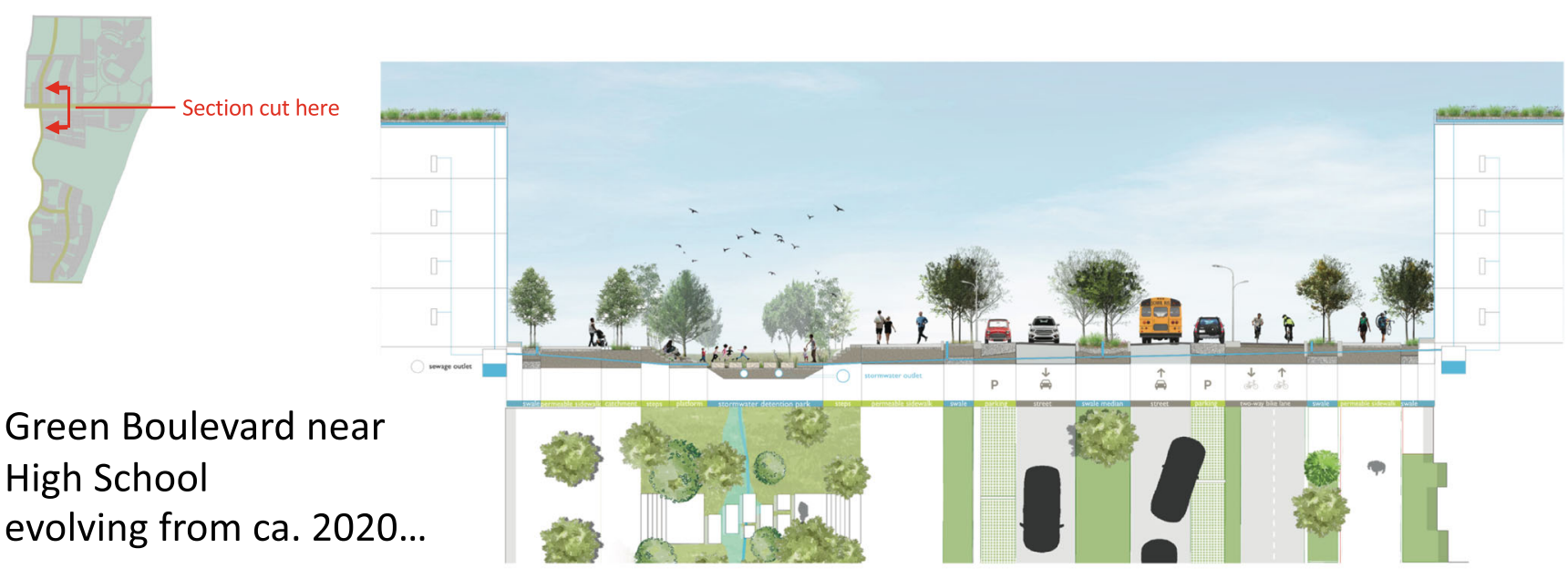

\section{Green Boulevard near High School evolving from ca. 2020...}

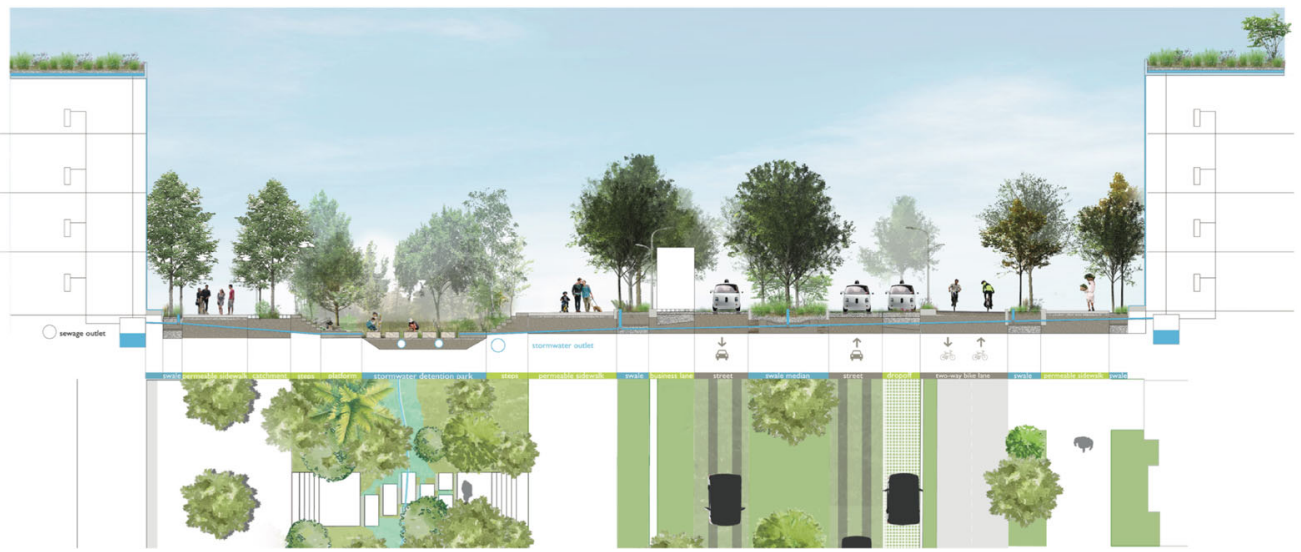

Fig. 4 Detail of Integrated Water Future Neighborhood Green Boulevard evolving from ca. 2020 to ca. 2060 
Table 4 Selected landscape metrics for the three alternative futures

\begin{tabular}{|c|c|c|c|}
\hline & $\begin{array}{l}\text { Current course } \\
\text { ca. } 2060\end{array}$ & $\begin{array}{l}\text { Stressed resources } \\
\text { future ca. } 2060\end{array}$ & $\begin{array}{l}\text { Integrated water } \\
\text { future ca. } 2060\end{array}$ \\
\hline \multicolumn{4}{|l|}{ Basin scale } \\
\hline $\begin{array}{l}\text { Cumulative forest area burned }{ }^{1} \\
(2010-2060)\end{array}$ & $\begin{array}{l}5012 \mathrm{~km}^{2} \\
(25 \% \text { of forested area) }\end{array}$ & $\begin{array}{l}14510 \mathrm{~km}^{2} \\
(71 \% \text { of forested area) }\end{array}$ & $\begin{array}{l}9435 \mathrm{~km}^{2} \\
(46 \% \text { of forested area) }\end{array}$ \\
\hline \multicolumn{4}{|l|}{ Watershed scale } \\
\hline New dwelling units & 3629 & 6107 & 5919 \\
\hline $\begin{array}{l}\text { Developed land area } \\
\text { (\% change from 2010) }\end{array}$ & $\begin{array}{l}1370 \text { ha } \\
(36 \%)\end{array}$ & $\begin{array}{l}1558 \text { ha } \\
(55 \%)\end{array}$ & $\begin{array}{l}1376 \text { ha } \\
(37 \%)\end{array}$ \\
\hline $\begin{array}{l}\text { Watershed imperviousness } \\
(\% \text { change from } 2010)^{2}\end{array}$ & $\begin{array}{l}18.3 \% \\
(28 \%)\end{array}$ & $\begin{array}{l}20.3 \% \\
(42 \%)\end{array}$ & $\begin{array}{l}18.9 \% \\
(33 \%)\end{array}$ \\
\hline $\begin{array}{l}\text { Protected land area } \\
\text { (\% change from 2010) }\end{array}$ & $\begin{array}{l}649 \text { ha } \\
(51 \%)\end{array}$ & $\begin{array}{l}390 \text { ha } \\
(-10 \%)\end{array}$ & $\begin{array}{l}1332 \mathrm{ha} \\
(209 \%)\end{array}$ \\
\hline Proportion of native bird habitat abundance at risk ${ }^{3}$ & $2.0 \%$ & $3.3 \%$ & $1.2 \%$ \\
\hline \multicolumn{4}{|l|}{ Neighborhood scale } \\
\hline Percent low/med/high density dwellings & $36 \% / 28 \% / 36 \%$ & $56 \% / 0 \% / 44 \%$ & $0 \% / 57 \% / 43 \%$ \\
\hline Neighborhood imperviousness & $63 \%$ & $72 \%$ & $55 \%$ \\
\hline $\begin{array}{l}\text { Green infrastructure } \\
\text { (\% of neighborhood) }\end{array}$ & $\begin{array}{l}32 \mathrm{ha} \\
(28 \%)\end{array}$ & $\begin{array}{l}16 \text { ha } \\
(14 \%)\end{array}$ & $\begin{array}{l}55 \mathrm{ha} \\
(48 \%)\end{array}$ \\
\hline
\end{tabular}

concerns with specificity, and group them into thematic, regionally plausible narratives. The next step to make the scenarios meaningful in a decision-making context, is to use evaluative models to compare and contrast the water management outcomes of the three alternative futures. Integrated evaluative models provide a tool for both pragmatic exploration of alternatives and theory building (Bach et al. 2014; Seppelt et al. 2009). When planners and decisions makers are involved, integrated models can become a tool for communities to ask "what if" questions about the future, and to articulate and visualize information helpful for long-range planning (Hulse et al. 2004; Nassauer and Opdam 2008; Steinitz 2012). In this section of the paper we highlight two challenges for modeling integrated UWS that are illustrated by this case study.

\section{Integrated modeling across scales}

Work with the SAC highlighted the need for water system models that represent both built and natural systems and can measure the cumulative effects of infrastructure choices. For example, members of the SAC advocated for a watershed perspective, arguing that it takes both site-scale stormwater management and basin-scale approaches such as preservation of riparian corridors, to minimize stormwater impacts on natural stream systems. They also argued that it is more cost-effective to preserve and restore exurban riparian areas, than to retrofit green infrastructure into developed areas with high real estate values. They noted that the riparian areas provided ecosystem and recreational co-benefits and specifically requested that the research team model and evaluate those benefits. In 2004, Clean Water Services, the regional water resources management utility for the Tualatin River Basin, received the nation's first watershed-based NPDES permit that combines wastewater and stormwater (City of Sherwood 2016b). The 2016 renewal of the stormwater permit also included a requirement that CWS assess and address watershed level hydromodification - changes in hydrologic characteristics which degrade water resources including stream erosion and changes in channel morphology (City of Sherwood 2016b).

Modeling the effectiveness of both site-scale and watershed-scale stormwater management is challenging because it spans typical modeling approaches and scales. Stormwater systems are typically designed and evaluated at the neighborhood or city scale with a focus on infrastructure performance up to the point of connection with the natural stream system. Conventional modeling tools developed for the purpose of stormwater engineering design, such as the EPA's Storm Water Management Model (SWMM) (Rossman 2015) facilitate site-scale stormwater design choices such as location and sizing of pipes, low-impact development features, and other water quality control measures. 
However, the cumulative effect of the stormwater control measures on natural channels, watershed hydrology and aquatic ecosystems is less frequently evaluated and less well understood (Jefferson et al. 2017). While storm drainage design models like SWMM are referred to as urban hydrologic models, Salvadore et al. (2015) comment that they are "not designed to analyze catchment-sized problems". Such models often simplify or do not represent processes such as subsurface flow and evapotranspiration, processes that are important for determining streamflow over larger space and time scales. In contrast, models that prioritize a watershed-scale perspective better represent water flow paths in the natural environment, but typically do not represent the details of flow through the stormwater network or the spatial heterogeneity of the urban environment (Salvadore et al. 2015). A lack of detailed data and the complexity of process interactions in the built environment, create uncertainty about predictions from these watershed-scale models (Salvadore et al. 2015; Bach et al. 2014).

If UWS of the future are to integrate across these systems, coupling the stormwater system and the natural stream system, for example, or linking re-used wastewater into the urban water supply system, then research and modeling tools will need to span these sectors, too. They will also need to employ modeling tools that managers consider sufficiently precise and reliable to use in real-world settings.

\section{Integrated modeling across disciplines}

Work with the SAC also highlighted the need for models that take into account both biophysical and socioeconomic controls on the water system, and that consider regional factors that operate beyond the city scale. For example, one of the initial concerns expressed in stakeholder meetings (Table 2) was the influence of exurban summer water demands on future water availability. Several stakeholders were engaged in the Willamette Basin Review, a process to reallocate water stored in federal reservoirs in the upper Willamette River Basin (USACE 2017). The reallocation process will determine how much stored water will be reserved for future municipal uses as well as for other water needs such as agricultural irrigation, and summer flow augmentation for water quality and habitat. Future water availability then is not only a function of urban water needs, but also of the regional water supply context, and the laws and institutions that control access to water.

These metrics of landscape response at each spatial extent (shown in Table 4) are the outcomes of process models and resulting representational models, intermediate stages in the workflow of a geodesign process. The next steps in that process include application of models to evaluate change and impact in the study units at each scale, with models appropriate to the purpose and scale of each evaluation.
Interest in the connection between biophysical and socioeconomic processes were part of the rationale for development of a coupled human-natural systems model for the Willamette River Basin called Willamette Envision (Turner et al. 2017; Jaeger et al. 2017). One of the goals of this model is to link biophysical controls on water availability such as snowpack accumulation and upland forest dynamics, with institutional controls on water availability such as water rights and reservoir operations. Integration of both human and natural systems in the model helped researchers identify unexpected interactions and feedbacks that affect water supply and demand. For example, simulations with warmer climate conditions created more wildfire in the $70 \%$ of the basin covered by forests (Hulse et al. 2016). The reduction in forest leaf area contributed to reduced evapotranspiration, and higher streamflows, despite the warmer climate conditions (Turner et al. 2017).

The Willamette Envision model illustrates the potential gains from modeling across disciplines and sub-systems. Bach et al. (2014) describe a classification scheme for integrated urban water models that corresponds with the types of infrastructure and water systems that the models represent. Those at the highest level of complexity are the coupled human-natural systems models, which Bach et al. (2014) label integrated urban water system models (IUWSMs). These models integrate across both disciplinary boundaries (e.g. economics, sociology, engineering, hydrology, ecology) and urban water infrastructure sectors (e.g. wastewater, stormwater, drinking water, natural stream systems). They note that few existing models achieve this level of integration and call for more interdisciplinary work to advance integrated modeling research. This case study illustrates that the interests and concerns of water managers support the need for this work.

\section{Conclusions}

Transdisciplinary research projects involving academics and agency professionals are well suited to exploring and testing the efficacy of new, innovative design options to evaluate multiple impacts on the urban water system in the broadest sense, including natural stream systems and the public perceptions of the livability of their neighborhoods. Such projects are often of interest to professional stakeholders precisely because they allow exploration of options many years in advance of when expensive commitments must be made to publiclyfunded infrastructure assets.

Numerous challenges must be overcome to develop the sustainable UWS of the future; among them the need to allow exploration of both locally intensive and spatially-extensive options for real innovation. The multi-scale alternative futures process described here highlights the benefits of a participatory process that engages partners across water management sectors to identify and explore integrative practices. 
Participation by local experts in the scenario design process helps identify innovations that are regionally plausible and feasible and creates a forum for stakeholders to explore and share innovative practices. The scenarios developed with this process also highlight the need to develop integrative models that consider links and feedbacks between water systems, and integrate across the biophysical and socioeconomic systems that influence urban water management.

Acknowledgements This work was supported by funding from the National Science Foundation, Grant number 1444758 (SRN: Urban Water Innovation Network (U-WIN): Transitioning Toward Sustainable Urban Water Systems. The authors gratefully acknowledge the contributions of the Stakeholder Advisory Committee and the assistance of Megan Little in Green Boulevard designs.

Open Access This article is distributed under the terms of the Creative Commons Attribution 4.0 International License (http:// creativecommons.org/licenses/by/4.0/), which permits unrestricted use, distribution, and reproduction in any medium, provided you give appropriate credit to the original author(s) and the source, provide a link to the Creative Commons license, and indicate if changes were made.

\section{References}

Bach PM, Rauch W, Mikkelsen PS, McCarthy DT, Deletic A (2014) A critical review of integrated urban water modelling - urban drainage and beyond. Environ Model Softw 54:88-107. https://doi.org/10. 1016/j.envsoft.2013.12.018

Baker JP, Hulse DW, Gregory SV, White D, van Sickle J, Berger PA, Dole D, Schumaker NH (2004) Alternative futures for the Willamette River basin, Oregon. Ecol Appl 14:313-324. https://doi.org/10. 1890/02-5011

Bolson J, Sukop MC, Arabi M, Pivo G, Lanier A (2018) A stakeholderscience based approach using the National Urban Water Innovation Network as a test bed for understanding urban water sustainability challenges in the U.S. Water Resour Res 54:3453-3471. https://doi. org/10.1029/2017WR021191

City of Sherwood (2014) Sherwood transportation system plan. Sherwood, Oregon. https://www.sherwoodoregon.gov/sites/default/ files/fileattachments/Engineering/page/608/sherwood_tsp_final_ tsp_volume_1_062714.pdf. Accessed 26 April 2019

City of Sherwood (2016a) Sherwood west preliminary concept plan. Sherwood, Oregon. https://www.sherwoodoregon.gov/planning/ page/sherwood-west-preliminary-concept-plan-approved. Accessed 26 April 2019

City of Sherwood (2016b) City of Sherwood Stormwater master plan. Sherwood, Oregon. https://www.sherwoodoregon.gov/sites/default/ files/fileattachments/Engineering/page/504/ordinance 2016-015 amend_chap_7_stormwater_masterplan_10.18.16.pdf. Accessed $2 \overline{6}$ April 2019

Ferguson L, Chan S, Santelmann M, Wright M (2016) Collaborative science-stakeholder engagement. Oregon Sea Grant, Corvallis, OR. https://seagrant.oregonstate.edu/sgpubs/collaborative-sciencestakeholder-engagement. Accessed 26 April 2019

Hering JG, Vairavamoorthy K (2018) Harvesting Experience to Support Sustainable Urban Water Management. In: Biswas AK, Tortajada C, Rohner P (eds.) Assessing Water Megatrends, Water Resources Development and Management, Springer, Singapore

Hulse D, Gregory S, Baker JP, Pacific Northwest Ecosystem Research Consortium (2002) Willamette River basin planning atlas: trajectories of environmental and ecological change. Oregon State University Press, Corvallis, OR http://www.fsl.orst.edu/pnwerc/ wrb/Atlas_web_compressed/PDFtoc.html. Accessed 11 Apr 2019.

Hulse D, Branscomb A, Payne S (2004) Envisioning alternatives: using citizen guidance to map future land and water use. Journal of Ecological Applications, 14(2), 325-341

Hulse D, Branscomb A, Enright C, Bolte J (2009) Anticipating floodplain trajectories: a comparison of two alternative futures approaches. Landsc Ecol 24:1067-1090. https://doi.org/10.1007/s10980-008-9255-2

Hulse D, Branscomb A, Enright C, Johnson B, Evers C, Bolte J, Ager A (2016) Anticipating surprise: using agent-based alternative futures simulation modeling to identify and map surprising fires in the Willamette Valley, Oregon USA. Landscape Urban Plann 156:2643. https://doi.org/10.1016/j.landurbplan.2016.05.012

Intergovernmental Science-Policy Platform on Biodiversity and Ecosystem Services (IPBES) (2016) The methodological assessment report on scenarios and models of biodiversity and ecosystem services. In: Secretariat of the intergovernmental science-policy platform on biodiversity and ecosystem services. Bonn, Germany https://www.ipbes.net/sites/default/files/downloads/pdf/2016. methodological_assessment_report_scenarios_models.pdf. Accessed 11 Apr 2019.

Jaeger WK, Amos A, Bigelow DP, Chang H, Conklin DR, Haggerty R, Langpap C, Moore K, Mote PW, Nolin AW, Plantinga AJ, Schwartz CL, Tullos D, Turner DP (2017) Finding water scarcity amid abundance using human-natural system models. Proc Natl Acad Sci USA 114:11884-11889. https://doi.org/10.1073/pnas.1706847114

Jefferson AJ, Bhaskar AS, Hopkins KG, Fanelli R, Avellaneda PM, McMillan SK (2017) Stormwater management network effectiveness and implications for urban watershed function: a critical review. Hydrol Process 31:4056-4080. https://doi.org/10.1002/hyp.11347

Koop SHA, van Leeuwen CJ (2015) Assessment of the sustainability of water resources management: a critical review of the City blueprint approach. Water Resour Manag 29:5649-5670. https://doi.org/10. 1007/s11269-015-1139-z

Lash JP (1980) Helen and teacher: the story of Helen Keller and Anne Sullivan Macy. Delacorte Press, New York

Liu Y, Mahmoud M, Hartmann H, Stewart S, Wagener T, Semmens D, Stewart R, Gupta H, Dominguez D, Hulse D, Letcher R, Rashleigh B, Smith C, Street R, Ticehurst J, Twery M, van Delden H, Waldick R, White D, Winter L (2007) Formal scenario development for environmental impact assessment studies. In: Jakeman A, Voinov A, Rizzoli AE, Chen S (eds.) State of the Art and Futures in Environmental Modeling and Software, IDEA Book Series, Elsevier

Liu Z, He C, Zhou Y, Wu J (2014) How much of the world's land has been urbanized, really? A hierarchical framework for avoiding confusion. Landsc Ecol 29:763-771. https://doi.org/10.1007/s10980014-0034-y

Mahmoud M, Liu Y, Hartmann H, Stewart S, Wagener T, Semmens D, Stewart R, Gupta H, Dominguez D, Dominguez F, Hulse D, Letcher R, Rashleigh B, Smith C, Street R, Ticehurst J, Twery M, van Delden H, Waldick R, White D, Winter L (2009) A formal framework for scenario development in support of environmental decision-making. Environ Model Softw 24:798-808. https://doi.org/10. 1016/j.envsoft.2008.11.010

Marlow DR, Moglia M, Cook S, Beale DJ (2013) Towards sustainable urban water management: a critical reassessment. Water Res 47: 7150-7161. https://doi.org/10.1016/j.watres.2013.07.046

Mitchell VG (2006) Applying integrated urban water management concepts: a review of Australian experience. Environ Manag 37:589605. https://doi.org/10.1007/s00267-004-0252-1

Mukheibir P, Howe C, Gallet D (2014) What's getting in the way of a "one water" approach to water services planning and management? In: Water: J Australian Water Assn, vol 41, p 67

Musacchio LR (2009) The scientific basis for the design of landscape sustainability: a conceptual framework for translational landscape 
research and practice of designed landscapes and the six Es of landscape sustainability. Landsc Ecol 24:993-1013. https://doi.org/10. 1007/s10980-009-9396-y

Nassauer JI, Opdam P (2008) Design in science: extending the landscape ecology paradigm. Landsc Ecol 23:633-644. https://doi.org/10. 1007/s10980-008-9226-7

NSF Advisory Committee for Environmental Research and Education (2018) Sustainable urban systems: articulating a long-term convergence research agenda. A report from the NSF advisory Committee for Environmental Research and Education. In: Prepared by the sustainable Urban Systems subcommittee

Owen DM (2015) Changing the paradigm: managing water throughout the cycle of total water solutions. J Am Water Works Assn 107:54-59

Prigogine I (2005) Surprises in a half-century. In: McDaniel RR Jr, Dreibe DJ (eds) Uncertainty and surprise in complex systems: questions on working with the unexpected. Springer Berlin Heidelberg, New York

Rastandeh A (2015) Challenges and potentials in using alternative landscape futures during climate change: a literature review and survey study. Urbani izziv 26:83-102

Rossman LA (2015) Storm water management model user's manual version 5.1. U.S. Environmental Protection Agency. https://www.epa. gov/water-research/storm-water-management-model-swmmversion-51-users-manual. Accessed 26 April 2019

Roth R, Mazza P (2017) A northwest vision for 2040 water infrastructure. Center for sustainable infrastructure, The Evergreen State College. https://www.evergreen.edu/sites/default/files/CSI-2040-WaterReport.pdf. Accessed 26 April 2019

Rupp DE, Abatzoglou JT, Hegewisch KC, Mote PW (2013) Evaluation of CMIP5 20th century climate simulations for the Pacific Northwest USA. J Geophys Res Atmos 118:10,884-10,906. https://doi.org/10.1002/jgrd.50843

Salvadore E, Bronders J, Batelaan O (2015) Hydrological modelling of urbanized catchments: a review and future directions. J Hydrol 529: 62-81. https://doi.org/10.1016/j.jhydrol.2015.06.028

Santelmann M, Freemark K, White D et al (2001) Applying ecological principles to land-use decision making in agricultural watersheds. In: Dale VH, Haeuber RA (eds) Applying ecological principles to land management. Springer, New York, New York, NY, pp 226-252

Seppelt R, Müller F, Schröder B, Volk M (2009) Challenges of simulating complex environmental systems at the landscape scale: a controversial dialogue between two cups of espresso. Ecol Model 220:34813489. https://doi.org/10.1016/j.ecolmodel.2009.09.009
Seto KC, Golden JS, Alberti M, Turner BL (2017) Sustainability in an urbanizing planet. Proc Natl Acad Sci U S A 114:8935-8938. https://doi.org/10.1073/pnas.1606037114

Sorte B and Rahe M (2015) Oregon agriculture, food and fiber: an economic analysis. Oregon State University Extension Service, Rural Studies Program. https://agsci.oregonstate.edu/sites/agsci. oregonstate.edu/files/oregon_agriculture_2015.pdf. Accessed 27 April 2019

Steinitz C (2012) A framework for Geodesign: changing geography by design. Esri Press, Redlands, Calif

Turner DP, Conklin DR, Bolte JP (2015) Projected climate change impacts on forest land cover and land use over the Willamette River Basin, Oregon, USA. Climatic Change 133(2), 335-48.https://doi. org/10.1007/s10584-015-1465-4

Turner DP, Conklin DR, Vache KB, Schwartz C, Nolin AW, Chang H, Watson E, Bolte JP (2017) Assessing mechanisms of climate change impact on the upland forest water balance of the Willamette River Basin, Oregon. Ecohydrology 10:n/a-n/a. https://doi.org/10.1002/ eco.1776

US Army Corp of Engineers (2017) Willamette Basin Review Feasibility Study - Draft Integrated Feasibility Report and Environmental Assessment. https://usace.contentdm.oclc.org/digital/collection/ p16021 coll7/id/8219. Accessed 26 April 2019

US Water Alliance (2016) One water roadmap: The sustainable management of life's most essential resource. http://uswateralliance.org/ sites/uswateralliance.org/files/publications/Roadmap\%20FINAL. pdf. Accessed 26 April 2019

van Leeuwen CJ, Frijns J, van Wezel A, van de Ven FHM (2012) City blueprints: 24 indicators to assess the sustainability of the urban water cycle. Water Resour Manag 26:2177-2197. https://doi.org/ 10.1007/s11269-012-0009-1

White D, Minotti P, Barczak M, Freemark K, Santelmann M, Kiester AR, Preston E (1997) Assessing risks to biodiversity from future landscape change. Cons Biol 11:349-360

Wilson, EO (2014) The meaning of human existence. New York, NY, US: W Norton \& Co.

Wodak J, Neale T (2015) A critical review of the application of environmental scenario exercises. Futures 73:176-186. https://doi.org/10. 1016/j.futures.2015.09.002

Wong THF, Brown RR (2009) The water sensitive city: principles for practice. Water Sci Technol 60:673-682. https://doi.org/10.2166/ wst. 2009.436

Wu H, Bolte JP, Hulse D, Johnson BR (2015) A scenario-based approach to integrating flow-ecology research with watershed development planning. Landscape Urban Plann 144:74-89. https://doi.org/10. 1016/j.landurbplan.2015.08.012 